\title{
THE NATURE OF LITERARY STUDY AFTER THE RISE OF CONTEMPORARY LITERARY THEORY
}

\author{
Dian Natalia Sutanto \\ Independent Researcher, West Borneo \\ dian_natalia_s@yahoo.co.uk \\ DOI: https://doi.org/10.24071/ijhs.2018.020109
}

Received 8 June 2018; revised 23 August 2018; accepted 1 September 2018

\begin{abstract}
Before the rise of contemporary literary theory, literary study mainly concerned with the nature, role, function of literary works and general schema for literary criticism. The rise of contemporary literary theories, such as structuralism, poststructuralism, psychoanalysis, feminism, new historicism, postcolonialism, and so on have changed the nature of literary study. By applying concepts and paradigms taken from other spheres of intellectual activity, such as culture, linguistics, aesthetics, politics, history, psychology, economics, gender, and so on, current literary study starts questioning and criticizing literary study basic assumptions. Contemporary literary theory brings a broad array of fundamental issues to attention, such as the act of reading, interpretative strategy, epistemology of literary scholarships, nationalism, genre, gender, originality, intertextuality, social hegemony, authorial intention, truth, representation and so on.
\end{abstract}

Keywords: literary criticism, literary study, literary theory

\section{Introduction}

Literary study is generally classified into two: literary criticism and literary theory. Literary criticism is a study of the concrete literary works through analysis, interpretation, explication or contextualization (Wellek, 1960; Hawthorn,1987). It's the oldest discipline in literary study as it goes at least as far back as archaic Greece that begins around 800 BC (Habib, 2005; Ford, 2002). Throughout the history of literary criticism, two strands of the discipline recur in form of rhetorical criticism and grammatical criticism (Day, 2008). Literary theory, on the other hand, concerns on theoretical principles and concepts that form the foundation for practical methods and strategies used in literary criticism (Castle, 2007).

In the old days, literary theory involved the general concern of the nature, role, function of literature and conceptual schemes for evaluating literary works. However, historical development shows that contemporary literary theory applied to literature seems less interested just in focusing on the nature of literary works itself and providing general schema for literary criticism. Contemporary literary theories, such as structuralism, poststructuralism, psychoanalysis, feminism, new 
historicism, and postcolonialism, actually are not 'literary' theory in nature. The theory derives from a non-literary system (Carter, 2006). For examples theory derives from culture, language and linguistics, aesthetics, politics, history, psychology, economics, gender, and so on applied to literary works in the interests of a specific critical aim. Contemporary literary theory thus grows out of this experimentation with concepts, terms, and paradigms taken from other spheres of intellectual activity (Castle, 2007). Throughout the history of literary theory, rises a whole range of theoretical approaches those focused on meaning and form, those that are political and those that are seemingly a-political (Bertens, 2007).

These contemporary theorists pay attention to a broad array of fundamental issues related to the reading, interpretative strategy, literature and culture, nationalism, genre, gender, originality, intertextuality, social hegemony, authorial intention, truth, representation and so on. Moreover, the contemporary theory has challenged the status and value of literary scholarship by raising epistemological objections to determine interpretations of literary texts (Shumway, 1985). Thus, it raises many protests from humanist scholars who seek a return of literary studies to traditional humanistic way. Many antitheorists claim that the theoretical enterprise should come to an end. Antitheorists are wrong to call for the end of theory and return to the unexamined literary traditions. Contemporary literary theories play important role as means of inspecting the gaps and failure of critical tradition and bringing self-aware scrutiny to the methods of literary study (Leitch, 2001). As claimed by Culler (2000) contemporary literary theory has radically changed the nature of literary study and criticism. This paper discusses how the contemporary theory has changed the nature of literary study.

\section{Theory}

\section{The Nature of Literary Study before Contemporary Literary Theory}

Literary theory has its roots in Plato's ideas on mimesis and Aristotle's Poetics which establishes the definitions of tragedy and comedy, and distinguishes poetry from history (Leitch, 2001; Goulimari, 2015). These classical Greece theories influence the literary study to see the nature of literary work as the representation of the universal truths about nature through the description of particular. Reading text and reading world are parallel activities.

In the medieval era, literary study focuses on the practice of reading, interpretation and theory of language. Augustine's hermeneutic theory proposes that language is transparent. Language truthfully portrays the world as it is, thus, truth is accessible through language. The foundation of literary criticism is developed under this medieval era through the influence of Quintilian's four level of allegorical interpretation: 1) literal or historical, 2) the allegorical or spiritual, 3 ) the tropological or moral, and 4) anagogical or mystical (Leitch, 2001).

In the Renaissance era, the national consciousness is growing and thus increases the preoccupation with distinct national literary tradition and the use of vernacular language (Patrick, 2007). In this era, Horatius proposes important doctrine of verisimilitude that means that literary works must depict historical realities and facts (Leitch, 2001).

In the Romantic era, general reflections on the nature of literature and criticism are still mainly sporadic as in the previous era. It is often arising from 
manifesto-like writings of particular authors and literary groups, or from contemporary commentary upon them, such as Sidney's Apology for Poetry, Wordsworth's preface to Lyrical Ballads, or Coleridge's Biographia Literaria. Romantic era is predominated by Kant's philosophy that subjectivity determines the apprehension of world (Durant, 2006). Literary works are seen as intimately bound with the personal impressions of the author. Thus, Schleiermacher calls for readers' sympathetic identification with the author. Literary work is also seen as organic form developed by author's imagination (Leitch, 2001; Childs, 2006).

The development of literary study through these eras has highly influenced the liberal humanism literary approach to literary works that predominates England in the mid of $19^{\text {th }}$ century. Basic tenets of liberal humanism approach to literary works are (Barry, 2009, pp.17-20):

1. "Good literature has timeless significance; it somehow transcends the limitations and peculiarities of the age it was written in, and thereby speaks to what is constant in human nature."

2. "The literary text contains its own meaning within itself. It doesn't require any elaborate process of placing it within a context, whether this be:

(a) Socio-political - the context of a particular social 'background' or political situation;

(b) Literary-historical - whereby the work could be seen as the product of the literary influences of other writers, or as shaped by the conventions of particular genres;

(c) Autobiographical - that is, as determined by the personal details of the author's life and thought."

3. "To understand the text well it must be detached from these contexts and studied in isolation. What is needed is the close verbal analysis of the text without prior ideological assumptions, or political pre-conditions."

4. "Human nature is essentially unchanging."

5. "Individuality is something securely possessed within each of us as our unique 'essence'."

6. "The purpose of literature is essentially the enhancement of life and the propagation of humane values; but not in a programmatic way: if literature and criticism become overtly and directly political they tend to be utilized as propaganda."

7. "Form and content in literature must be fused in an organic way, so that the one grows inevitably from the other."

8. "Sincerity (comprising truth-to experience honesty towards the self, and the capacity for human empathy and compassion) is a quality which resides within the language of literature."

9. "What is valued in literature is the 'silent' showing and demonstrating of something, rather than the explaining, or saying, of it."

10. "A theoretical account of the nature of reading or of literature in general, isn't useful in criticism and will simply, if attempted, encumber critics with preconceived ideas which will get between them and the text."

In this era, it can be seen that literary study is heavily stressed on the criticism rather than on the theorization of literature. Literary criticism is dominated by empiricism. Thus, it can be understood why the liberal humanist opposed the application of contemporary literary theory from other study fields. 


\section{Theory Application}

\section{The Nature of Literary Studies and Criticism Under the Contemporary Theory}

Early twentieth century shows the transition from traditional literary theory to contemporary literary theory which is adopted from outside the field of literary study, such as linguistics, politics, history, psychology, economics, gender, and so on. Theory of criticism begins to be a more self-conscious activity, and more independent of the creative writing of the time. The first theorists which develop a conceptual framework for the understanding of literature were the Russian Formalists and the Prague Linguistic Circle. This more systematic attitude to theory spread to Germany, and then to England and America. In the 1970s, literary theory enters a new phase dominated by philosophy, history, politics, and psychoanalysis.

Theory in this stage develops along two main pathways. First are text-based theories, such as New Criticism, Formalism, Structuralism, and Poststructuralism. Text-based theories focus on the analysis of language, signs, or systems of signification. Second is historicist theories such as Marxism, Feminism, New Historicism, and Postcolonialism. Historicist theories focus on the critique of social, cultural and historical conditions and the way these conditions are reflected in and altered by cultural form like literary text (Castle, 2007).

Contemporary theories have radically changed the nature of literary studies because it challenges the traditional literary study assumptions or common-sense. A common-sense view of the world gives the illusion of unity and completeness. Theory is always the enemy of common sense; it is the spirit of subversion in the world of thought (Selden, 1991). Many unexamined concepts in literary study are under scrutiny by contemporary literary theory, such as meaning, interpretation, nature and function of literature. Theory has changed people's views and thought differently about objects of literary study and activities of studying literature. Contemporary theory challenges these traditional literary theory assumptions (Selden, 1991; Shumway, 1985):

1. a literary text is an object which has a meaning which is unified, univocal and definite inside it;

2. the author is the origin of the text and its meaning, and that the author's intention is the only authority for interpretation;

3. the reader is a passive reflector of the author's intended meaning or the text's structure;

4. reading does not affect the meaning of a literary text, because the reader discovers it from a position of Parnassian detachment: the instruments of criticism are perfectly sterilized

5. literary canon represent politically neutral values that everyone within a given culture might be expected to affirm.

The blow on the common sense of literary study is culminated with the coming of Derrida's deconstruction in 1960s. Deconstruction attacks on the core or essence of the text which refers to: spiritual truth, transcendental essence, the author's intention, teleology, social reality, etc. Derrida argues that no text can sustain the logic of its own discourse without somewhere violating it (Eagleton, 2005; Norris, 2002). The multi-accented nature of language always resists the mastery of truth and logic. Deconstructive reading requires readers to be critical in 
unresolved issues of a text, such as contradiction, paradox, indecision, and logical tension in a text (Norris, 2018; Stocker, 2006).

The contemporary literary theory challenges the status and value of literary study by raising epistemological objections in determining the interpretations of literary texts. According to Belsey the central problem of literary theory is the problem of meaning (Belsey, 1982). Literary theory could not claim of its own impartiality of standing outside of contest for meaning (Belsey, 1982).

The common-sense of the traditional literary study assumes that literary text tells a certain truth which is communicated to us through the undistorted or transparent language. A literary work is thought of as being governed by a spiritual essence, or a transcendental sign. The readers are trying to discover a truth which the literary work illustrates. The act of reading itself does not influence the meaning of the text and thus literary criticism can be done in objective way solely based on the literary text. All of these traditional literary study assumptions are challenged by contemporary literary theory.

The basic assumption of contemporary literary theory is that facts, meaning, value, reason and nature are construction, not objective or unchanging realities. This basic tenet can be traced back to the work of Saussure and Bakhtin. Saussure proposes that a sign not as a sign of something. Its relation to the signified is relational and arbitrary (Barry, 2009; Culler, 1986). The individual signifier always carries with it the multiple possibilities of signification it derives from the multiplicity of its existing signifieds. A word can remain the same, but the meaning varies in history and depends to its context. Thus, the meaning does not precede language. Bakhtin, on the other hand, establishes a discursive view of language which claims that language is dialogic, the site of ideological contestation (Gardiner, 1992). Every utterance is potentially the site of a struggle for meaning between competing discourses and voices (Pope, 2002). Language cannot be separated from its social context. Language is always contaminated, interleaved, opaquely coloured by layers of semantic deposits resulting from the continuing processes of human struggle and interaction. Words are therefore inevitably marked by ideological struggle; they are multi-accentual, not univocal. Words speak of a conflict of perspectives (Selden, 1991).

Even though, contemporary literary theories have different approaches and traditions, based on the previous explained basic assumptions it can be seen that these theories share several similar ideas that have changed the nature of literary study (Barry, 2009):

1. Politics is pervasive;

"Theorists generally believe that all thinking and investigation is necessarily affected and largely determined by prior ideological commitment. Every practical procedure (for instance, in literary criticism) presupposes a theoretical perspective of some kind."

2. Language is constitutive;

"Language conditions, limits, and predetermines what we see. Thus, all reality is constructed through language, so that nothing is simply 'there' in an unproblematical way everything is a linguistic/ textual construct."

3. Truth is provisional; 
'Instead of being solidly 'there' in the real world of fact and experience, they are 'socially constructed', that is, dependent on social and political forces and on shifting ways of seeing and thinking."

4. Meaning is contingent;

"The meanings within a literary work are never fixed and reliable, but always shifting, multi-faceted and ambiguous. In literature, as in all writing, there is never the possibility of establishing fixed and definite meanings: rather, it is characteristic of language to generate infinite webs of meaning, so that all texts are necessarily self-contradictory."

5. Human nature is a myth

"Theorists distrust all 'totalising' notions. 'Human nature', as a generalised norm which transcends the idea of a particular race, gender, or class, is to be distrusted too, since it is usually in practice Eurocentric (that is, based on white European norms) and androcentric (that is, based on masculine norms and attitudes). Thus, the appeal to the idea of a generalised, supposedly inclusive, human nature is likely in practice to marginalise, or denigrate, or even deny the humanity of women, or other disadvantaged groups."

Contemporary literary theory has changed the nature of literary study by bringing forth these consequences to the literary study:

The indeterminacy of literary works' meaning does not mean the negation of the literary criticism, but it renders the value of such interpretation relative to the purposes of the criticism. Literary criticism cannot claim to be impartial and objective. It cannot longer stand outside the contests for meaning it identified because all critics operate within specific ideological positions. As a knowledge itself, it is inevitably a location of power and contests for power.

It is unavoidable that canonical status of literary works is being questioned and reexamined. Aesthetic evaluation on literature would be irrelevant because the boundaries of literature as a value and a category are not unchanging.

In literary reception, the readers are demanded to be skeptical with everything they have taken for granted from literary works. Rereading are required in order to seek out those elements in a text which are most alien or repressed or most radically discontinuous with what the readers take for granted.

It is unavoidable for critics to recast the received interpretations of old texts and frameworks. The critics should have to keep revealing interesting new zones of meaning and possibilities from literary works for future critical inquiry.

Literary theory remains valuable as long as it persists in being theoretical by continually criticizing its own dogmatism. When literary theory becomes self enclosed area and distant itself from critical movement, then it is no longer being theoretical. Theory must not only be assertive in advocating particular theory, but it must always be analytical to its own theory. Thus, theory always means criticism.

\section{Conclusion}

Contemporary literary theory has drastically changed the nature of literary study by questioning and criticizing literary study basic assumptions. It has changed the nature of literary study into unstable and uncertain quest of texts, meanings, identities, values, and truth. The relevance of its quest is relative and relevance only in certain socio-cultural contexts. It would have never achieved the 
stability, uniformity, consistency and universality as science has achieved across social and cultural contexts.

\section{References}

Barry, P. (2009). Beginning theory: An introduction to literary and cultural theory. Manchester: Manchester University Press.

Belsey, C. (1982). Problems of literary theory. New Literary History 14(1), 175182, https://www.jstor.org/stable/468964.

Bertens, H. (2007). Literary theory: The Basics. London and New York: Routledge.

Carter, D. (2006). Literary theory. Herts: Pocket Essentials.

Castle, G. (2007). The Blackwell guide to literary theory. Oxford: Blackwell Publishing.

Culler, J. (1986). Ferdinand de Saussure. Ithaca: Cornell UP.

Culler, J. (2000). Literary theory: A very short introduction. Oxford: Oxford University Press.

Childs, P. (2006). Texts: Contemporary cultural texts and critical approaches. Edinburgh: Edinburgh UP.

Day, G. (2008). Literary criticism: A new history. Edinburgh: Edinburgh UP.

Durant, W. (2006). The story of philosophy. New York: Pocket Books.

Eagleton, T. (2005). Literary theory: An introduction. Oxford: Blackwell Publishing.

Ford, A. (2002). The origins of criticism : Literary culture and poetic theory in classical Greece. New Jersey: Princeton UP.

Gardiner, M. (1992). The dialogics of critique: M.M.Bakhtin and the theory of ideology. London and New York: Routledge.

Goulimari, P. (2015). Literary criticism and theory: From Plato to Postcolonialism. London and New York: Routledge.

Habib, M.A.R. (2005). A history of literary criticism: From Plato to the present. Oxford: Blackwell Publishing.

Hawthorn, J. (1987). Unlocking the text: Fundamental issues in literary theory. London: Edward Arnold.

Leitch, V.B. (2001). The Norton anthology of theory and criticism. New York: W.W. Norton \& Company.

Norris, C. (2002). Deconstruction. London and New York: Routledge.

Norris, C. (2018). Deconstruction. In Richter, David H (Ed.), A Companion to Literary Companion (pp.100-113). Hoboken: John Wiley \& Sons Ltd.

Patrick, J. (2007). Renaissance and reformation. New York: Marshall Cavendish.

Pope, R. (2002). The English studies book: An introduction to language, literature, and culture. London and New York: Routledge.

Selden, R. (1991). Does literary studies need literary theory? Critical Survey, 3(1), 96-103, http://www.jstor.org/stable/41555559.

Shumway, D. (1985). Why we should teach theory (instead of "literature")?. The Journal of the Midwest Modern Language Association, 18(2), 14-19, http://jstor. org/stable/1315182.

Stocker, B. (2006). Derrida on deconstruction. London and New York: Routledge. 
IJHS, e-ISSN 2597-4718, p-ISSN 2597-470X, Vol. 1, No. 2, March 2018, pp. 134-150

Wellek, R. (1976). Concepts of criticism. New Haven and London: Yale University Press. 